\title{
ESPÍRITUS LIBRES: EL ALUMBRADISMO Y MIGUEL SERVET
}

\author{
POR \\ María TAusiet \\ Centro de Ciencias Humanas y Sociales, CSIC, Madrid
}

\section{RESUMEN}

El simbolismo de la luz, asociada al conocimiento y a la elevación espiritual, se encarnó en la España del siglo XVI en una supuesta nueva herejía de signo ambiguo. El llamado «alumbradismo» fue condenado y perseguido sin que nunca llegara a definirse claramente la ideología de sus pretendidos adeptos. Como espiritualista radical, Servet compartía con los alumbrados un tipo de sensibilidad religiosa centrada en el cultivo de la interioridad. El pensamiento servetiano, aunque más elaborado que el atribuido a los llamados alumbrados, coincidía también con el de éstos en un optimismo teológico sin límites. En ambos casos, la defensa de la libertad interior era la pieza clave de una religiosidad basada en el sentimiento de confianza inspirado por un Dios concebido como puro amor. Las numerosas similitudes entre Servet y los alumbrados se enmarcan en el contexto europeo de reforma religiosa generalizada, pero no se explican únicamente por ello. La biografía de Servet incita a pensar que podrían tener una razón mucho más directa, y, en muchos aspectos, reveladora.

PALABRAS ClAVE: Espiritualismo, Religiosidad interior, Alumbrados, Servet

\section{FREE SPIRITS:}

\section{ALUMBRADISMO AND MICHAEL SERVETUS}

\begin{abstract}
In sixteenth-century Spain, the symbolism of light, so closely associated to the concepts of knowledge and spiritual elevation, was embodied in a so-called new heresy of ambiguous nature. Known as alumbradismo, or illuminism, it was condemned and persecuted without the ideology espoused by its alleged adepts ever being clearly defined. Michael Servetus, himself a radical spiritualist, shared with the so-called alumbrados a kind of religious sensibility centred on the cultivation
\end{abstract}


of interiority. While Servertus's thinking was more complex than that attributed to the alumbrados, the two strands also had in common a sense of boundless theological optimism. Safeguarding inner freedom was, for both, key to a religiosity based on the trust inspired by a God conceived of as pure love. The many similarities between Servetus and the alumbrados can be set in the European context of widespread religious reform, but are not accounted for by this alone. Servetus's life story points to a far more direct, and, in many ways, revealing explanation.

KEY WORDS: Spiritualism, Inner religiosity, Alumbrados, Servetus

$$
\begin{array}{ll}
\text { Recibido/Received } & \text { 17-09-2009 } \\
\text { Aceptado/Accepted } & 01-06-2012
\end{array}
$$

«Alumbrar a uno es encaminarle en la verdad, porque sin ella va a ciegas» ${ }^{1}$ «La luz es lo más hermoso de este mundo, y del otro» ${ }^{2}$

El simbolismo de la luz, asociada desde antiguo al conocimiento y a la elevación espiritual, se encarnó en la España del siglo XVI en una supuesta nueva herejía de signo ambiguo. ${ }^{3}$ El llamado «alumbradismo» fue condenado y perseguido por la Inquisición a lo largo de dos siglos sin que nunca llegara a definirse claramente la ideología de sus pretendidos adeptos. En realidad se trataba de un término irónicamente despectivo ya que, frente a los auténticos «iluminados» por la luz de Dios, los llamados «alumbrados» no serían sino falsos místicos, guiados (o más bien desencaminados) por el demonio. Nada más significativo que el primer testimonio que se conserva de esta expresión utilizada como escarnio y aplicada a un franciscano visionario de Ocaña (Toledo), a quien en 1512 se acusó de estar «alumbrado con las tinieblas de Satanás». ${ }^{4}$

${ }^{1}$ Covarrubias, S. 1993. Tesoro de la lengua castellana o española: 106 Barcelona: Alta Fulla.

${ }^{2}$ Servet, M. 2003-2007. Christianismi Restitutio (Restitución del cristianismo), I, IV, en A. Alcalá (ed.), Miguel Servet. Obras completas, vol. V: 256. Zaragoza: Prensas Universitarias.

${ }^{3}$ Véase Pastore, S. 2004. Un'eresia spagnola: Spiritualità conversa, alumbradismo e inquisizione (1449-1559) Florencia: Olschki (trad. esp. 2010. Una herejía española. Conversos, alumbrados e Inquisición (1449-1559) Madrid: Marcial Pons).

${ }^{4}$ Carta de fray Antonio Pastrana al cardenal Cisneros (27 de agosto de 1512). El fraile franciscano acusado de alumbrado había escandalizado a sus superiores al confesar sentirse llamado por Dios para engendrar a un profeta que salvaría el mundo. Para tal fin, había escrito a la célebre monja sor Juana de la Cruz, quien a su vez lo denunció a Pastrana. Véanse Fuente de la, V. 1855. Historia eclesiástica de España, vol. III: 102. Barcelona: Riera; Meléndez y Pelayo, M. 1947 [1 $1^{\mathrm{a}}$ ed. 1880-1882]. Historia de los heterodoxos españoles, vol. II: 174 Madrid: BAC; Serrano y Sanz, M. 1903. «Pedro Ruiz Alcaraz, iluminado alcarreño del siglo XVI». Revista de Archivos, Bibliotecas y Museos VIII : 2; Bataillon, M. 1937. Erasme et l'Espagne. Recherches sur l'histoire spirituelle du XVI siècle Paris: Droz (trad. esp. 1966. Erasmo y España. Estudios sobre la historia espiritual del siglo xvr: 68 Madrid: Fondo de Cultura Económica); Selke, A. 1968. El Santo Oficio de la Inquisición: proceso de Fr. Francisco Ortiz Madrid:

Hispania Sacra, LXV

131, enero-junio 2013, 73-102, ISSN: 0018-215-X, doi: 10.3989/hs.2013.003 
Teniendo en cuenta el origen satírico y paródico del término, resulta comprensible que los propios acusados no se denominaran a sí mismos alumbrados. Como apunta Antonio Márquez, ni siquiera sabían que lo fuesen. El calificativo era externo. Lo que llegó a conocerse como «doctrina de los alumbrados» fue resultado de una sistematización desde la perspectiva inquisitorial de datos muy dispersos y no siempre fiables, pues procedían de una mezcla aportada tanto por los denunciantes como por los propios reos. De ahí que el llamado alumbradismo englobe posturas y sensibilidades muy distintas. ${ }^{5}$

Lo que sí puede afirmarse es que dicha etiqueta, de uso generalizado a partir de los años 1523-1525, ${ }^{6}$ terminó utilizándose por los representantes de la Iglesia con la pretensión de distinguir en esta vida algo tan impalpable y dudoso como la verdadera de la falsa santidad. Ante la proliferación creciente de quienes aseguraban experimentar éxtasis, revelaciones, impulsos proféticos u otros fenómenos de origen místico, se hacía necesario un criterio de discernimiento que pusiera orden en medio de tanta confusión. ¿De dónde procedían esas efusiones de sentimiento religioso? ¿De Dios? ¿O acaso más bien del mismo diablo, que siempre procuraba engañar por los medios más sutiles e insospechados?7

La obsesión por el discernimiento espiritual suponía ante todo el intento de controlar un tipo de religiosidad alejada de lo institucional que cada vez iba contando con más partidarios. A partir del siglo xvI, a lo largo de toda Europa, tanto protestante como católica, se multiplicaron los defensores de un cristianismo interiorizado, al margen de signos externos, de intermediarios y jerarquías, de sacramentos y rituales, y, en suma, de cualquier posible interposición entre el hombre y lo divino. La interiorización de la vivencia religiosa implicaba la aspiración a una perfecta unión con Dios mediante la contemplación y el progresivo abandono a su voluntad, con el consiguiente despojamiento del yo. Más que basada en un conocimiento de tipo intelectual, dicha unión tendía a experimentarse como algo emotivo, lo que la hacía accesible a cualquiera,

Guadarrama, y Márquez, A. 1980. Los alumbrados. Orígenes y filosofía (1525-1559): 70-71 Madrid: Taurus.

${ }^{5}$ Véase Márquez, A. 1980: 72-81.

${ }^{6}$ Véase Ortega, M. 1978. Proceso inquisitorial contra María de Cazalla (1534): 56 Madrid: Fundación Universitaria Española.

${ }^{7}$ Sobre el discernimiento espiritual, véanse Lea, H. Ch. 1983. Historia de la Inquisición española, vol. III: 369-47 Madrid: Fundación Universitaria Española; Caciola, N. 2003. Discerning Spirits: Divine and Demonic Possession in the Middle Ages Ithaca: Cornell University Press; Keitt, A. 2005. Inventing the Sacred. Imposture, Inquisition, and the Boundaries of the Supernatural in Golden Age Spain Leiden: Brill, y Sluhovsky, M. 2007. Believe Not Every Spirit. Possession, Mysticism, \& Discernment in Early Modern Catholicism Chicago: University of Chicago Press. 
por más ignorante e iletrado que fuera. No se trataba, por tanto, de oponer una razón contra otra razón, sino de un intenso sentimiento personal que no admitía discusión. ${ }^{8}$

La unión mística se asociaba con una renuncia al propio ego pero, paradójicamente, convivía al mismo tiempo con una firme confianza en las propias capacidades, lo que, desde el punto de vista de la Iglesia institucional, resultaba altamente peligroso. Sin duda, el cultivo de la propia interioridad derivaba en un incremento de la seguridad en uno mismo, pero no sólo en eso. Expresada en el lenguaje religioso de la época, dicha seguridad implicaba un paso más allá: la convicción de vivir en gracia de Dios y la certeza de la salvación eterna. El optimismo inherente a tales presupuestos resultaba inseparable de un profundo sentimiento de libertad espiritual, materializada en otro tipo de libertades más explícitas que a menudo chocaban con la moral imperante. Asimismo, la defensa de un estado anímico alegre, de una espiritualidad menos centrada en la pasión, el arrepentimiento y las lágrimas que en el regocijo por la resurrección, llegó a condenarse como impía, cuando no herética.

Todas estas tendencias, que eclosionaron en España en la primera mitad del siglo xvi, habían ido fraguándose lentamente a lo largo de la Edad Media, especialmente a partir del siglo XIV. ${ }^{9}$ Buen ejemplo de ello son los llamados «Hermanos del Libre Espíritu», una supuesta secta con presencia en Flandes y Renania a la que se atribuyeron determinados rasgos que veremos reproducidos dos siglos después como acusaciones en muchos procesos españoles contra alumbrados. ${ }^{10}$ Los acusados del Libre Espíritu carecían en su mayoría de una formación intelectual sólida, pero las ideas por las que fueron condenados enraizaban estrechamente con las defendidas por teólogos contemporáneos de la talla de Eckhart, Suso o Tauler, lo que nos da una muestra del tipo de creencias que pretendían combatirse. ${ }^{11}$ De forma similar, aunque el abismo cultural existente entre la mayoría de los acusados de alumbradismo y el teólogo Miguel Servet resulte incuestionable, una inmersión en el sistema de pensamiento del sabio aragonés, y en particular en su exquisita y elaborada «teología de la luz», en

${ }^{8}$ Véanse Bainton, R. H. 1952. The Reformation of the Sixteenth Century: 123-140 Boston: The Beacon Press, y Dickens, A. G. 1966. Reformation and Society in Sixteenth Century Europe: 125-149 Londres: Thames \& Hudson.

${ }^{9}$ Véanse Foley, A. E. 1986. «El alumbradismo y sus posibles orígenes», en A. D. Kossoff, G. Ribbans, J. Amor y Vázquez (eds.), Actas del VIII Congreso de la Asociación Internacional de Hispanistas: 527-532. Madrid: Istmo, y Santonja, P. 2000. «Las doctrinas de los alumbrados españoles y sus posibles fuentes medievales». Dicenda. Cuadernos de Filología Hispánica 18: 353-392.

${ }^{10}$ Véase Lerner, R. E. 1972. The Heresy of the Free Spirit in the Later Middle Ages Berkeley-Los Angeles-Londres: University of California Press.

${ }^{11}$ Véase Libera de, A. 1996. Eckhart, Suso, Tauler et la divinisation de l'homme Paris: Bayard (trad. esp. 1999. Eckhart, Suso, Tauler y la divinización del hombre Palma de Mallorca: J. J. de Olañeta).

Hispania Sacra, LXV

131, enero-junio 2013, 73-102, ISSN: 0018-215-X, doi: 10.3989/hs.2013.003 
gran medida todavía desconocida, nos ayudará a comprender mejor el ambiente espiritual del momento.

\section{DEIFICACIÓN}

Al igual que los alumbrados españoles, los acusados de pertenecer a la herejía del Libre Espíritu no constituían en absoluto un grupo organizado. En palabras de Robert E. Lerner, «algunos herejes del Libre Espíritu fueron condenados antes de que pudiera probarse que muchos de ellos habían existido». ${ }^{12} \mathrm{En}$ realidad, los juzgados por pertenecer a la secta apenas tenían nada en común, salvo una creencia difusa en la posibilidad de unirse a Dios sin ningún tipo de mediación sacramental o clerical. Dicha aspiración no se alejaba en lo esencial del misticismo ortodoxo. Pero lo que resultaba verdaderamente escandaloso e inadmisible para las autoridades religiosas era que la unión con Dios se concibiera como algo posible en esta vida, sin necesidad de esperar al Más Allá.

Sin duda, la contribución más original de los llamados hermanos del Libre Espíritu radicaba en su convicción acerca de la capacidad del hombre para alcanzar un estado divino en la tierra. Semejante idea suponía un optimismo teológico desconocido en la Edad Media que sólo volvería a resonar con una fuerza comparable a finales del siglo XV en la encendida defensa del amor humano que Pico della Mirandola incluyó en su Discurso sobre la dignidad del hombre («quien es un serafín, esto es, un amante, está en Dios, y lo que es más, Dios está en él, y Dios y él son uno solo).» ${ }^{13}$

Pese a su probada independencia intelectual y religiosa, el teólogo dominico alemán conocido como maestro Eckhart también acabó siendo relacionado con la supuesta herejía del Libre Espíritu, debido a su apología de la divinización del hombre. En 1322 se produjo en Colonia una persecución masiva de begardos y beguinas que culminó con la muerte de muchos de ellos, ya fuera quemados en la hoguera, ya ahogados en el río Rhin, y cuatro años después se inició un proceso inquisitorial contra Eckhart con el que pretendía detenerse la difusión de sus peligrosas ideas entre la gente sencilla. Tales ideas, malentendidas y malinterpretadas, se derivaban de lo que tanto Eckhart como otros místicos renanos contemporáneos reconocían como la unión inseparable, profunda y misteriosa, de dos gracias: la de la Encarnación y la de la Inhabitación. Esta

${ }^{12}$ «Heretics of the Free Spirit were condemned before very many of them can be proved to have existed». Véase Lerner, R. E. 1972: 61.

${ }^{13}$ Véase Pico della Mirandola, G. 2004 [1 $1^{\mathrm{a}}$ ed.1496]. Oratio de Hominis Dignitate, en C. Llano Cifuentes (ed.), Discurso sobre la dignidad del hombre: 19. Ciudad de México: Universidad Autónoma de México. 
unión se resumía en una tesis que acabó por convertirse en refrán: «Dios se hizo hombre para que el hombre se haga Dios». ${ }^{14}$

Tanto la tesis de la Encarnación de Dios en la persona de Jesucristo como la de la Inhabitación, o habitación de la Trinidad en el alma del justo, eran perfectamente ortodoxas. Ambas había sido defendidas por los primeros Padres de la Iglesia, entre ellos Ireneo de Lyon, Atanasio, Clemente de Alejandría e incluso San Agustín. Como escribía Ireneo: «Ésa es la razón por la que el Verbo se hizo hombre, y el Hijo de Dios, hijo del hombre: para que el hombre, al mezclarse con el Verbo y recibiendo así su filiación adoptiva, se convierta en Hijo de Dios». ${ }^{15}$ El propio Tomás de Aquino había profesado la doctrina de un Dios no sólo omnipresente, sino particularmente presente en ciertas almas, en las cuales habitaba «como en su templo». ${ }^{16}$ Sin embargo, una cosa era la teología especulativa y otra muy diferente la vivencia interiorizada de la religión y su desarrollo místico. Lo que llegó a ser considerado como inaceptable fue no sólo esa «mezcla» de lo divino y lo humano, sino más aún, el concepto de «vida bienaventurada» que predicaba incansablemente Eckhart y que se fundamentaba en su convicción de que existe «una beatitud accesible en la tierra», una suerte de traducción cristiana de la «felicidad intelectual» defendida por los filósofos aristotélicos del siglo XIII. ${ }^{17}$

La condena de dichas ideas se basaba en el supuesto orgullo y megalomanía de quienes aspiraban a identificarse con Dios. Que el alma pudiera llegar a hacerse una con la divinidad implicaría al menos dos herejías: por un lado, autoteísmo y, por otro, antinomianismo, o rechazo de las leyes morales, ya que cada uno podría hacer lo que quisiera, sin otro criterio que el inspirado por la propia conciencia. Ello significaría la abolición del concepto de pecado y la consiguiente apertura a todo tipo de conductas libertinas. La interpretación de la pretendida impecabilidad, o incapacidad para pecar, defendida por los herejes del Libre Espíritu y más adelante por los alumbrados españoles, se fundamentaba, no obstante, en un malentendido tras otro, producto del temor a los posibles excesos derivados de la excepcional independencia espiritual de quienes aspiraban a participar de lo divino.

Frente a las acusaciones de practicar todo tipo de conductas viciosas, ${ }^{18}$ la mayoría de quienes aspiraban a la unión mística intentaban alcanzarla, muy al

\footnotetext{
${ }^{14}$ Véase Libera de, A. 1996: 23.

${ }^{15}$ Contra las herejías, III, 19, 1 .

${ }^{16}$ Summa teologica, I, 43, 3 .

${ }^{17}$ Sobre la llamada «Teología de la Beatitud», véase Libera de, A. 1996: 37.

${ }^{18}$ Un ejemplo extremo es la descripción de los alumbrados que hacía Marcelino Menéndez Pelayo a finales del siglo XIX, según la cual: «El nombre de secta, o el de herejía, parece demasiado blando para semejante gavilla de facinerosos que, realmente, sólo querían vivir a sus anchas y regodearse como
} 
contrario, mediante el ascetismo y la abnegación. Era idea comúnmente admitida que al encuentro íntimo con Dios sólo podía llegarse por la humildad y, sobre todo, por la renuncia y el desprendimiento. El desapego del yo comportaba un abandono de la propia voluntad y, en consecuencia, una actitud de entrega a la voluntad divina, lo que permitía la creación de un auténtico vacío, o, dicho de otro modo, de una disponibilidad y apertura que, paradójicamente, conducían a la más alta dicha mediante la aceptación de lo más bajo. El conocimiento de Dios por la vía del desconocimiento y el progresivo desprendimiento suponían, por tanto, un esfuerzo considerable: transformarse en Dios no era una tarea nada fácil, sino todo lo contrario. La divinización se creía posible, sí, pero sólo mediante un largo camino en pos de la libertad interior. Además, nadie podía «deificarse» por su propia decisión (algo a lo que precisamente había que renunciar de continuo), sino por decisión o gracia divina. Para Eckhart, el «espíritu libre» era el que estaba desprendido y, en consecuencia, vacío, disponible, abierto. No se trataba tanto (o no sólo) de una liberación de las prácticas religiosas exteriores - la oración vocal, los sacramentos, etc. - como de un cambio radical de la actitud interior («¿Qué es un espíritu libre? Un espíritu libre es aquél que no se perturba por nada ni está atado a nada, ni ha unido lo mejor de sí a ningún modo, ni mira por lo suyo en cosa alguna; completamente sumido en la muy cara voluntad de Dios, ha salido de sí mismo»). ${ }^{19}$

En el lenguaje de los alumbrados españoles, la deificación se traducía en un «dejamiento» a la voluntad divina, lo que no equivalía a un abandono a las inclinaciones naturales - como a menudo se interpretó-, sino más bien a un intento de superar pasiones y deseos individuales difíciles de desarraigar. El mayor peligro, desde el punto de vista de los inquisidores, estribaba en el radicalismo moral de dicha postura, que representaba un completo alejamiento del formalismo religioso y sus rutinas devotas. Quienes defendían el dejamiento lo asociaban sobre todo con un sentimiento profundo de amor y aceptación, tanto de los demás como de uno mismo, lo que se consideraba como la auténtica vía para la deificación, tal y como se reflejaba en afirmaciones del tipo de «el amor de Dios en el hombre es Dios» o, yendo un poco más allá, «el corazón del hombre es Dios». ${ }^{20}$ Según Mari Núñez, testigo en el proceso inquisitorial contra Pedro Ruiz de Alcaraz, «este reo decía que aquel que se deja a Dios o suspende

brutos animales» (Historia de los heterodoxos españoles, vol. II, p. 190). Este tipo de apreciaciones tuvieron continuidad hasta muy avanzado el siglo xx. Así, por ejemplo, Álvaro Huerga, aun admitiendo la existencia de «un alumbradismo de buena ley», se refería a otro alumbradismo, «degenerado», a una «fase pornográfica de la secta», o a la «lubricidad seudomística» de ciertos adeptos. Véase, de 1978, su Historia de los alumbrados (1570-1630). vol. I: 8-13 Madrid: Fundación Universitaria Española.

${ }^{19}$ Maestro Eckhart. 1983. Pláticas instructivas (o Reuniones vespertinas de conversación), II, en I. M. de Brugger (ed.), Tratados y sermones: 87. Barcelona: Edhasa.

${ }^{20}$ Véase Márquez, A. 1980: 184. 
todo acto de voluntad en Dios, [...] el 'dexado a Dios', es impecable, de tal manera que no puede pecar mortal ni venialmente» $\mathrm{y}$, asimismo, que «Dios estaba en él, y él en Dios, de tal manera que no podía pecar venialmente». ${ }^{21}$

Las consecuencias de tal sentimiento eran rotundas para Pedro Ruiz de Alcaraz: «Que los que están en esta suspensión del alma en Dios no están obligados a dar cuenta de su alma al confesor»; que un hombre «así abandonado, no necesitaba de ayunos ni de obras de misericordia», «que la ciencia impide al hombre [...] esta suspensión del ánimo»; «que se contentasen con lo que Dios les infundía, porque la letra mata el espíritu»; «que el amor les enseñaría lo que había que hacer»; «que los que hacen penitencia [...] se llaman 'lloraduelos'»; «que no quería que estas cosas se hiciessen, a saber: llevar cilicio, disciplinarse, ayunar, orar vocalmente y otras obras exteriores que mueven a devoción». Según varios testigos en su proceso, Alcaraz «se burlaba, menospreciaba y tenía en nada el derramamiento de lágrimas procedentes de la memoria de los pecados, o de la Pasión de Cristo». A Catalina Hernández, «le parecía [...] que el reo se reía o no tenía en nada la Pasión de Cristo». Como opción alternativa al arrepentimiento de los pecados, con sus consecuentes mortificaciones, Alcaraz afirmaba que «la penitencia no es necesaria»; que «lo que necesita la persona es quedarse quieta, sentada, y esperar la promesa de Dios», y «que cuando le viene alguna tentación o mal pensamiento a una persona, que no lo debe resistir, sino dejarlo así en el alma, porque en esto hay más mérito». ${ }^{22}$

En relación con la clásica dicotomía entre buenos y malos pensamientos, tradicionalmente identificados con tentaciones demoníacas, Gaspar de Bedoya, otro reo juzgado por alumbradismo, «aconsejaba a cierta persona que permaneciese suspensa, dejando todos sus pensamientos, y se pusiese en quietud, sin que tuviese consigo ni buen ni mal pensamiento, porque cuando la persona estaba sin pensamiento, permanecía en paz». ${ }^{23}$ Para Isabel de la Cruz ${ }^{24}$ «toda la vida del alma consistía en eso: [en] que Dios hiciese su voluntad en nosotros, sin contradicción nuestra». ${ }^{25}$ Fuera de dicha aceptación, el resto de manifestaciones religiosas carecían de significado. Más aún, adquirían un carácter sospechoso, por ser muestras gratuitas de ostentación que sólo servían para establecer

${ }^{21}$ Este proceso, que incluye otros dos procesos más contra acusados de alumbradismo, lleva por título en la primera página: «Guadalajara. Año 1529. Contra Pedro Ruiz de Alcaraz e, incidentalmente, contra Isabel de la Cruz y Gaspar de Bedoya, sobre proposiciones escandalosas y hereticas como alumbrados», Archivo Histórico Nacional (AHN), leg. 106, $\mathrm{n}^{\circ}$ 5. Véase un sumario de dichos procesos en Márquez, A. 1980: 243-293.

${ }^{22}$ Ibídem: 247-260.

${ }^{23}$ Ibídem: 289.

${ }^{24}$ Sobre Isabel de la Cruz, véase Bainton, R. H. 1977. Women of the Reformation, from Spain to Scandinavia: 18-27 Minneapolis: Augsburg.

${ }^{25}$ Véase Márquez, A. 1980: 264. 
comparaciones odiosas en este mundo: «iOh, quién no oyese: éste es más o menos!». ${ }^{26}$ Según uno de los testigos en su proceso, Isabel «se indignaba con las ostentaciones exteriores, como darse golpes de pecho, signarse con el signo de la cruz en diversas partes del cuerpo [...] y así de otros signos de la cruz que los que asisten a misa suelen hacer». Y, en palabras de Juan Gallego, «la rea decía a cierta persona que no se humillase a besar la tierra [...] por temor a lo que la gente diga [...] que permaneciese quieto». A él mismo había llegado a aconsejarle, al verle juntar las manos cuando oraba, «que no las juntase, para que la gente no dijera que era más santo que los otros». ${ }^{27}$

Isabel no sólo menospreciaba las obras exteriores de devoción, como los sacramentos ${ }^{28} \mathrm{o}$ el culto a las imágenes ${ }^{29}$ sino que además rechazaba todo concepto de autoridad, tomando como presupuesto que a Dios sólo se llegaba por la vía del amor, no de la obediencia: «Confesó la rea que estando en el amor de Dios, que sentía en sí misma, y en el deseo que tenía de aprovechar a los prójimos, no estaba obligada a obedecer sino a aquéllos que estaban en el amor de Dios. Y de allí le venía que no obedeciese a su madre, ni a sus superiores, porque los tenía por imperfectos [...], que no salían de los límites del amor propio, y que de lo que desconocían, blasfemaban». ${ }^{30}$

El énfasis en el amor desprendido o desinteresado como vía para la unión con Dios se revela de forma inequívoca en el estremecedor proceso contra María de Cazalla, juzgada como alumbrada por la Inquisición de Toledo en 1534. Teniendo en cuenta las posibilidades reales de encauzar su vida amorosa para una mujer del siglo XVI, fundamentalmente el matrimonio y la vida conventual (una opción intermedia era el beaterio, donde se recogían algunas solteras para llevar una vida piadosa), las críticas de María resultan impactantes en el contexto de su época. Para ella, ambos estados constituían ejemplos de amor interesado o, lo que es peor, de una auténtica "prostitución espiritual». ${ }^{31}$ Según Diego Hernández, testigo en su proceso, María le había confesado en cierta ocasión: «Que le matava que el mundo dispusiese de sus hijas [y ] o las casase o las metiese monjas». Y que «en los casamientos [...] no se aman syno por los dineros y por la hermosura. No veo onbre christiano a quien dé mis hijas, que

\footnotetext{
${ }^{26}$ Ibídem: 265.

${ }^{27}$ Ibídem: 269.

28 «Decía la rea que más perfectamente estaba Dios en el alma que en el sacramento [de la Eucaristía]». Ibídem: 277.

${ }^{29}$ «La rea decia que las imágenes eran los libros de los inferiores o ignorantes. Y, hablando irónicamente, decía que bien se le estaba a aquél, o que bien le iban las cosas a aquél que tenía que acordarse de Dios por las imágenes». Ibídem: 274.

${ }^{30}$ Ibídem: 267-268.

${ }^{31}$ Expresión utilizada por Milagros Ortega en su libro de 1978, Proceso inquisitorial contra María de Cazalla: 399.
} 
me pareçe que no es más casarlas agora que ponerlas a la putería». ${ }^{32}$ En cuanto a la opción de la vida conventual, de acuerdo con este mismo testigo, sus palabras habían sido: «Meterlas monjas, véolas a ellas apartadas deste propósito. Veo una profanidad en los monasterios, que no sé [...] qué Dios ay allí. Que me dijo fray Gil el otro día que antes fuesen putas que monjas [...] y que han de obedecer allí a un madero que les dan por rey, como allá dizen de unas ranas». ${ }^{33}$

Centrándonos en la propia María, las confesiones íntimas sobre su vida sexual y sobre el camino que recorrió hasta su personal deificación o fusión con lo divino constituyen un testimonio de todo punto extraordinario. Según María, hacía ocho o diez años ya que había dejado de sentir «aquellos regocijos que solía en la deletaçión carnal», lo que le había llevado a consultar con sus confesores «sy hera posible conçebir a sus fijos syn deletaçion», pues «no los quería como a sus fijos, syno como a fyjos de sus vecinos». Al ser preguntada por los inquisidores a qué atribuía su falta de placer, respondió que desde hacía años se había ocupado «en obras de penitencia, e en guardar e refrenar sus sentidos lo mejor que podía». ${ }^{34}$ Tal y como consta en las actas del proceso, en otra de sus declaraciones ante los jueces había afirmado que, como en el pasado había sido «muy flaca y tentada de la carne, acordándose de lo que dize Sant Pablo - que gustado el sp[írit]u es desabrida toda carne, y gustada la carne es desabrido todo sp[írit]u -, se hazía mucha fuerça, y con muy gran pena pagaba la deuda. Y por no caer en desorden y delectaçion, se ponía en pensar un paso de la Pasión, o en el Juizio universal, o en suplicar a Dios que la obra que allí se hiziese fuese para su serviçio». Según la propia María, el efecto de tales meditaciones era inmediato y contudente: «como se ocupaba de esto, no sentía el deleyte carnal». ${ }^{35}$

De acuerdo con el testimonio de Mari Núñez, durante una época, María había llegado al extremo de negar a su marido «el débito carnal [...], syno fuese para lo que tocaba a la generaçion», cosa que le reprocharon sus confesores («le dezían que no hazía bien»). Pese a reconocer abiertamente «que no se confesava

${ }^{32}$ Ibídem: 81 .

${ }^{33}$ Ibídem: 81. Como afirma Milagros Ortega, «se mezclan aquí la fábula de las ranas y el pensamiento muy erasmiano de que no hay que confundir el madero de la cruz con el crucificado» (p. 94). Según la fábula de Júpiter y las ranas, atribuida a Esopo, las ranas, que vivían libremente en su laguna, pidieron a Júpiter que les concediera un gobernador para castigar a las que errasen entre ellas. Entonces Júpiter decidió burlarse enviándoles un gran madero a modo de jefe. Pero pronto comprobaron «que era madero en el qual no avía espíritu de vida. E llegando más cerca, subieron sobre él e hollaron e pisáronlo con los pies». Véase La vida y fabulas del Ysopo, Valencia, Juan Joffré, 1520, fol. 22v. Una de las acusaciones más repetidas contra los alumbrados era que se negaban a adorar la cruz, a la que consideraban un simple pedazo de madera carente de espíritu.

${ }^{34}$ Véase Ortega, M. 1978: 113-114.

35 Ibídem: 119. 
syno por conplir por el mundo, e que no le acusava la conçiençia de nada», ${ }^{36}$ parece que no desoyó el consejo sacerdotal ya que, de hecho, volvió a mantener relaciones sexuales con su marido («haziendo todo lo quél quería»). Dicha aceptación le llevaría más tarde a admitir que «estando ella en el acto carnal con su marido, estava más allegada a Dios que si estoviese en la más alta oración del mundo y $[\ldots]$ que cuando su marido le pagava la debda marital estava toda divina». ${ }^{37}$

Esta última afirmación llamó especialmente la atención de los inquisidores, siendo calificada de proposición herética, «falsíssima y perniçiosa, y escandalosa». ${ }^{38} \mathrm{Y}$ es que no cabe duda de que, fuera cual fuera el método aducido, tales pretensiones de divinización representaron uno de los mayores peligros a combatir por las autoridades religiosas en el contexto de la reforma radical de las conciencias que tuvo lugar en España y en general en toda Europa durante la primera mitad del siglo xvi. ${ }^{39}$ Buen ejemplo de ello es, sin duda, el pensamiento del teólogo y científico Miguel Servet, quien no dudaba en afirmar que «la divinidad está injerta en la mente humana» y que «el alma del hombre es consustancial con Dios». ${ }^{40}$ Según Servet, éste era el motivo por el que San Pablo había asegurado que «todos los hombres son de estirpe divina». ${ }^{41}$ De manera más o menos velada, todo el programa servetiano de regeneración espiritual apunta a una definitiva deificación del hombre. ${ }^{42}$ Construida pieza a pieza a través de imágenes y metáforas en torno a la dicotomía luz/sombra, la original y potente teología del pensador aragonés se manifiesta como un proceso de progresiva espiritualización capaz de superar las tinieblas del materialismo y la ignorancia.

${ }^{36}$ Ibídem: 63.

${ }^{37}$ Ibídem: 64.

${ }^{38}$ Ibídem: 34.

${ }^{39}$ Sobre la relación entre disidencia religiosa y misticismo, y, en particular, sobre la deificación, véase Ozment, S. E. 1973. Mysticism and Dissent. Religious Ideology and Social Protest in the Sixteenth Century: 46-50 New Haven y Londres: Yale University Press.

40 «Esse mentis hominis insitam divinitatem esseque animam Deo homoousios consubstantialem». Servet, M. 2003-2007. Epistolae Triginta ad Ioannem Calvinum (Treinta cartas a Calvino), carta XXII, en A. Alcalá (ed.), Obras Completas, vol. IV: 98 y 320.

41 “Unde Paulus omnes homines ait esse progeniem divinam". Ibídem:. 96 y 318. Servet se refiere aquí a la cita de la Carta de San Pablo a los Efesios en la que utiliza la expresión «miembros de la familia de Dios» («Ya no sois extranjeros ni advenedizos, sino conciudadanos de los santos y miembros de la familia de Dios», Efesios, 2: 19).

${ }^{42}$ Como señala George H. Williams, los representantes de la llamada «reforma radical» solían abstenerse de emplear el término teológico tradicional de «santificación». Preferían, en cambio, insistir en otros conceptos, como «regeneración», «hombre nuevo», «restitución» (en el caso de Servet) o, en un lenguaje más o menos velado, «deificación». Véase Williams, G. H. 1962. The Radical Reformation: XII Kirksville: Sixteenth Century Journal Publishers (existe una versión resumida traducida el español en 1983. La reforma radical, Ciudad de México: Fondo de Cultura Económica). 


\section{VITA ABSCONDITA}

Como espiritualista radical, Servet compartía con los acusados de alumbradismo un tipo de sensibilidad religiosa centrada en el cultivo de la interioridad, con todas las consecuencias - teóricas, pero también prácticas - que ello implicaba. ${ }^{43} \mathrm{El}$ pensamiento servetiano, aunque incomparablemente más elaborado que el atribuido a los alumbrados, coincidía asimismo con el de éstos en un optimismo teológico sin límites. En ambos casos, la defensa de la libertad interior, y de la libertad en general, eran piezas clave de una religiosidad basada en el profundo sentimiento de confianza inspirado por un Dios concebido como puro amor. La insistencia de Servet en proclamar el libre albedrío frente a la doctrina de la predestinación de Calvino no es sino una muestra más de ese optimismo inquebrantable que subrayaba la gracia y el perdón divinos por encima de la justicia y las leyes humanas. ${ }^{44} \mathrm{La}$ identificación de Dios con la utopía del amor perfecto implicaba asimismo una ardiente apología de la impecabilidad humana, lo que venía a restaurar la inocencia primordial de quienes decidían confiar en la providencia o, en el lenguaje de los alumbrados, dejarse.

Tanto para Servet como para los alumbrados, la ciencia - entendida como cultivo de la razón lógica - representaba un obstáculo para el verdadero conocimiento. En palabras de Pedro Ruiz de Alcaraz, «la ciencia impide al hombre, y lo indispone o hace incapaz de esta suspensión del ánimo, es decir, de este estado de perfección por el cual el hombre se abandona a Dios o [...] totalmente se dexa en Dios». ${ }^{45}$ La misma idea aparecía formulada por Servet en sus continuas referencias a la serpentina sapientia (sabiduría serpentina): «esa deidad de la serpiente que es la sabiduría del mundo». ${ }^{46}$ Para Servet, el saber profano procedía de la serpiente-demonio «que camufla lo verosímil como verdadero, y compone lo verdadero con lo falso». ${ }^{47}$ De ahí la «ceguera de los hombres» («cuán grande sea la ceguera de los hombres, lo apreciamos nosotros en las obras de los demás. Lo mismo piensan ellos acerca de nosotros, mas 'nadie ve la viga en su ojo'» ${ }^{48}$ ). Andando el tiempo, dichas ideas serían reformuladas con una claridad insuperable por François Fénelon, al asegurar que «nuestro mal

${ }^{43}$ Véase Moreno Moreno, D. 2011. Miguel Servet, teólogo iluminado: ¿ortodoxia o herejía? Zaragoza: Institución Fernando el Católico.

${ }^{44}$ Véase Tausiet, M. 2010. «Mago contra Falsario: Un duelo de insultos entre Calvino y Servet». Hispania Sacra, 62, 125: 181-211.

${ }^{45}$ Véase Márquez, A. 1980: 280.

${ }^{46}$ Servet, M. 2003-2007. Christianismi Restitutio (Restitución del cristianismo), IV, I, en A. Alcalá (ed.), Obras completas, vol. VI: 948.

${ }^{47}$ Ibídem: 954.

${ }^{48}$ Ibídem: 973. 
consiste en nuestra pasión por razonar» ${ }^{49}$ pues la razón es limitada, incierta, defectuosa, y continuamente falla al comparar, discernir, prever, concluir, etc. ${ }^{50}$

Sin negar a la razón humana su valor intrínseco, tanto Servet como los alumbrados insistían en el impedimento que la excesiva erudición suponía para penetrar en los misterios divinos. Tomando como punto de partida el evangelio de San Lucas («escondiste estas cosas a los sabios y entendidos, y las revelaste a los pequeños [sencillos] $»^{51}$ ), Isabel de la Cruz aseguraba tener «a los varones letrados por incapaces y no idóneos para [...] esta suspensión del alma en Dios», de tal forma que «éstos que se decían alumbrados se tenían a sí mismos por los pequeñuelos [del Evangelio]».52 Asimismo, Pedro de Alcaraz llegó a confesar haber enseñado a algunos «que no fuesen demasiado ávidos al leer la Sagrada Escritura [...], sino que se contentasen con lo que Dios les infundía, porque la letra mata el espíritu». ${ }^{53}$ En varias ocasiones a lo largo de su extensa obra, pese a su propia e impactante erudición, Servet iba a volver sobre la misma idea: «Cristo no hablaba a filósofos expertos en hipóstasis, sino al pueblo, a niños y a mujeres»; ${ }^{44}$ «otro es el camino de la verdad, no conocido de los metafísicos, sino de los idiotas y los pescadores». ${ }^{55}$

Del mismo modo, el rechazo de los alumbrados hacia las devociones externas iba a encontrar un eco redoblado en los feroces ataques de Servet contra lo que él denominaba «tradiciones y robos sagrados» o, lo que es lo mismo, contra todo lo que no fuera una vivencia exclusivamente interiorizada de la religión. Así, si Isabel de la Cruz exhortaba a sus discípulos a «que no se cuidasen de las maceraciones de la carne [...], ni de ayunos y oraciones, ni de pensar en la Pasión [...], porque todas estas cosas son de poco valor [...] rastreras y bajas», ${ }^{56}$ Servet dedicaba los peores improperios a la «idolatría papista» que para él empezaba por el culto a Dios en los templos, con sus imágenes y reliquias; continuaba en

49 «Notre mal ne consiste que dans notre passion pour raisonner. C'est notre sagesse intempérante et éloignée de toute sobriété, laquelle nous travaille comme une fièvre ardente qui met en délire», Carta II, sobre la gracia y la predestinación. 1851-1852, en «Lettres spirituelles», François Salignac de la Mothe Fénelon. Euvres complètes, vol. II: 181. Paris: Gaume.

${ }^{50}$ Varillon, F. 1957. Fénelon et le pur amour: 125-126 Paris: Seuil. Sobre la actitud ambivalente de Fénelon, de confianza y de desconfianza en la razón al mismo tiempo, véase Lagrée, J. 1996 «Quiétude et inquiétude de la raison: Fénelon et Leibniz», en D. Leduc-Fayette (ed.), Fénelon, philosophie et spiritualité: 39-62. Ginebra: Droz.

${ }^{51}$ San Lucas, 10: 21.

52 Véase Márquez, A. 1980: 264.

${ }^{53}$ Ibídem: 260.

${ }^{54}$ Servet, M. 2003-2007. De Trinitatis Erroribus (De errores acerca de la Trinidad), II, en A. Alcalá (ed.), Obras completas, vol. II. I: 258.

${ }^{55}$ Servet, M. 2003-2007. Epistolae Triginta ad Ioannem Calvinum (Treinta cartas a Calvino), VII, en A. Alcalá (ed.), Obras completas, vol. IV: 36.

${ }^{56}$ Véase Márquez, A.1980: 266. 
las peregrinaciones, con sus votos y exvotos, con la costumbre de arrodillarse y santiguarse, la devoción a las ánimas del purgatorio, o la venta de bulas e indulgencias, sin excluir las misas o cualquier otro tipo de méritos o sacrificios. Desde el punto de vista de Servet, tales manifestaciones eran corrupciones del auténtico y primitivo cristianismo, formas arbitrarias de piedad sin valor alguno y, lo que es más, signos inequívocos del Anticristo. ${ }^{57}$ En sus propias palabras:

«Si repasamos las demás tradiciones sagradas, comprobarás cómo nuestros sacerdotes observan más y peores que los mahometanos. En una cosa aventajan los mahometanos a los papistas: en que detestan los ídolos y aborrecen inmensamente la idolatría papística. A pesar de que Dios no habita en templos hechos a mano, ni se le puede dar culto con manos humanas, sino sólo con espíritu; sin embargo, los sacerdotes papistas dedican muchos templos al culto de muchos santos y guardan en sus altares muchos cadáveres. Fabrican artísticamente estatuas, ídolos e imágenes de oro, plata, bronce, hierro, madera, piedra, adornándolas con hermosas pinturas; colocan dentro de estos ídolos reliquias de cadáveres, los llevan en hombros e invocan a uno en caso de peste, a otro en la tormenta, y a otros en otras enfermedades. Organizan peregrinaciones y hacen votos a éste por sus bueyes, a aquél por sus ovejas, a otros por los caballos y asnos, y de esta guisa resultan tantas divinidades como ciudades y aldeas [...]. Dicen también nuestros sacerdotes que hay que presentar ante el altar de estas divinidades pan, vino y otras ofrendas, y atender al ornato de sus altares con nuestro propio peculio; que tenemos que encender cirios alrededor de esas imágenes para iluminar los cadáveres; que debemos ofrecerles votos, inclinarnos ante ellos con la cabeza descubierta, arrodillarnos y besarles devotamente los pies [...]. Nos enseñan que tenemos que rezar a las ánimas de los difuntos, que representan esas imágenes. Dicen también que en virtud de las bulas selladas que han recibido de la Bestia, no sólo podemos alcanzar indulgencias para nuestros pecados, sino incluso para librar de sus penas a los muertos. Y añaden que con sus misas, méritos y sacrificios serán liberadas del infierno las almas de nuestros difuntos y antepasados, y purgada su alforja en el purgatorio». ${ }^{58}$

Contra esto, Servet insistía una y otra vez en que «no tenemos que ofrecer sacrificios corporales, sino espirituales», para lo cual no es necesario ningún sacerdote: «El único sacrificio agradable a Dios es el del espíritu. Todos nosotros, por ser partícipes de Cristo, somos verdaderos sacerdotes en virtud de la unción de espíritu santo realizada en nosotros». ${ }^{59} \mathrm{Al}$ igual que para los alumbrados (Alcaraz decía «que no se confesaba con el sacerdote sino para satisfacer al

57 Véase su opúsculo Signa Sexaginta Regni Antichristi, et revelatio eius, iam nunc praesens (Sesenta signos del reino del Anticristo, y su revelación ya en la actualidad), en A. Alcalá (ed.), Obras completas, vol. IV: 141-155.

${ }^{58}$ Servet, M. 2003-2007. Christianismi Restitutio (La restitución del cristianismo), IV, II, I, en A. Alcalá (ed.), Obras completas: 1030-1031.

${ }^{59}$ Ibídem: 1049.

Hispania Sacra, LXV

131, enero-junio 2013, 73-102, ISSN: 0018-215-X, doi: 10.3989/hs.2013.003 
mundo», ${ }^{60}$ que «no quería que entre el hombre y Dios hubiese medio», ${ }^{61} \mathrm{y}$ «que a Dios se ha de adorar interiormente» ${ }^{62}$ ), para Servet, la vida del espíritu no sólo era interior sino, más aún, oculta, escondida, completamente inaccesible: «Esta vida, por la que vivimos espiritualmente en Dios [...], está escondida, pues ha dejado de ser externa y se ha interiorizado». ${ }^{63} \mathrm{Al}$ hombre del Antiguo Testamento, dependiente de ceremonias y rituales, «le ha sucedido otro hombre interior, que vive sólo espiritualmente [...] Hombre interior. Hombre escondido en el corazón (1 Pedro, 3: 4). A este hombre no lo conoce el mundo». ${ }^{64}$

La vita abscondita, entendida como la verdadera vida espiritual, es defendida por Servet a lo largo de su obra y manifiesta una constante tensión entre lo visible y lo invisible: «Todo cuanto hay en el mundo es perceptible de un modo u otro [...], aunque llamemos invisibles a las [cosas] que se perciben por otro modo más espiritual que la vista». Del grado de sutileza de cada ser dependerá su percepción de los distintos tipos de realidad:

«Invisible llamamos al aire, pero perceptible. Invisible, por ser más tenue que la agudeza de nuestra mirada. El mismo espíritu divino, que como un aura suave inspira nuestras almas, se nos hace perceptible, aunque sea invisible. A las criaturas celestes con forma de ángeles las llamamos visibles, y a las que tienen forma de espíritus, invisibles para nosotros, aunque sean en sí visibles [... ]. Como entre los hombres, así también entre esos espíritus unos mandan en otros y les sobrepasan en agudeza, excelencia, agilidad, tenuidad y esplendor. Tienen unos mayor torpeza que otros, y menor entendimiento». ${ }^{65}$

Una vez más, Servet y los alumbrados coincidían en su aborrecimiento de las obras meramente exteriores, pero más aún de la idea de que éstas tuvieran correspondencia alguna con el verdadero espíritu de santidad. Para Sebastian Franck, otro destacado representante del ala radical de la Reforma, la auténtica iglesia de Cristo era invisible. ${ }^{66}$ La idea de la invisibilidad de los santos se basaba en principio en la rebelión protestante contra cualquier expresión exte-

\footnotetext{
${ }^{60}$ Véase Márquez, A. 1980: 250.

${ }^{61}$ Ibídem: 256.

${ }^{62}$ Ibídem: 254.

${ }^{63}$ Servet, M. 2003-2007. Christianismi Restitutio (La restitución del cristianismo), IV, II, I, en A. Alcalá (ed.), Obras completas, vol. VI: 1212.

${ }^{64}$ Ídem.

${ }^{65}$ Servet, M. 2003-2007. Epistolae Triginta ad Ioannem Calvinum (Treinta cartas a Calvino), VII, en A. Alcalá (ed.), Obras completas, vol. IV: 17-18.

${ }^{66}$ «Creo que la Iglesia externa de Cristo, con todos sus dones y sacramentos, a causa de la irrupción y de la devastación perpetradas en ella por el Anticristo inmediatamente después de los apóstoles, subió al cielo y permanece escondida en el Espíritu y en la verdad [...]. Mediante el Espíritu, y a través de su iglesia espiritual, Dios proveyó todas las cosas de las cuales los signos exteriores no eran más que un anuncio; y ha permitido que el demonio, que no busca otra cosa que las exterioridades, haga mal uso de estas exterioridades y sea el manipulador de los sacramentos». Citado en Williams, G. H. 1962: 497.
} 
rior del mérito humano, como la penitencia o las indulgencias. ${ }^{67}$ Las huellas de meritoriedad, las acciones dignas de alabanza, resultaban en principio sospechosas en tanto que proyectadas hacia una exterioridad forzada. Sólo así se entiende la indignación de Isabel de la Cruz ante las «ostentaciones exteriores» pero, sobre todo, ante la mala costumbre de comparar quiénes eran mejores y quiénes peores ( «iOh, quién no oyese: éste es más o menos!» ${ }^{68}$ ). Según el cuarto artículo de la acusación fiscal contra Pedro de Alcaraz, «cuando alguno le decía al reo que había más méritos en una persona que en otra, decía este reo exclamando: ¡Oh, quién no oyese este más o menos! Por donde parece dar a entender que no hay grados en los méritos». ${ }^{69}$

Las numerosas similitudes de sensibilidad entre Servet y los alumbrados se enmarcan en el contexto europeo de reforma generalizada y, en concreto, en la línea radical de los conocidos como «espiritualistas». ${ }^{70}$ Dentro de España, los diferentes movimientos hacia un cristianismo cada vez más interiorizado y emotivo tuvieron un peso tan importante que incluso ha llegado a hablarse de un «renacimiento espiritual» entre los años $1520-1566 .{ }^{71}$ No obstante, las coincidencias entre el alumbradismo y el pensamiento de Servet no se explican únicamente por la atmósfera espiritual que se respiraba en aquellos momentos. La biografía de Servet empuja a pensar que podrían tener una razón mucho más directa, sorprendente $y$, en muchos aspectos, reveladora. ${ }^{72}$

Aunque falta todavía mucho por aclarar en la vida del aragonés, sabemos de su nacimiento en Villanueva de Sijena (Huesca), casi con toda certeza en $1511 .{ }^{73}$ Era hijo de un notario reputado en la comarca, lo que induce a pensar

${ }^{67}$ Véase Williams, G. H. 1962: 929-931.

${ }^{68}$ Véase Márquez, A. 1980: 265.

${ }^{69}$ Ibídem: 249.

${ }^{70}$ Sobre el espiritualismo, un término utilizado a menudo por la historiografía para designar a ciertos reformadores europeos de carácter radical pero pacífico al mismo tiempo, como Hans Denck, Sebastian Franck, Caspar Schwenckfeld, Henry Niclaes, David Joris y, en España, Miguel Servet y Juan de Valdés, entre otros, véanse: Bainton, R. H. 1952: 123-141; Dickens, A. G. 1966: 141-150; Williams, G. H. 1983: 492-541, 809-839, y 875-894; Leclerc, J.1955. Histoire de la tolérance au siècle de la Réforme Paris: F. Aubier (trad. esp. 1969. Historia de la tolerancia en el siglo de la Reforma Alcoy: Marfil); Firpo, M. 1990. Tra alumbrados e 'spirituali': studi su Juan de Valdés e il valdesianesimo nella crisi religiosa del '500 italiano Florencia: Olschki (trad. esp. 2000. Entre alumbrados y «espirituales». Estudios sobre Juan de Valdés y el valdesianismo en la crisis religiosa del '500 italiano. Madrid: Fundación Universitaria Española) e ídem (trad. John Tedeschi). 1996. «The Italian Reformation and Juan de Valdés». Sixteenth Century Journal, 27, 2: 353-364.

${ }^{71}$ Véase Pego Puigbó, A. 2004. El Renacimiento Espiritual. Introducción literaria a los tratados de oración españoles (1520-1566) Madrid: CSIC.

${ }^{72}$ Véase Márquez, A. 1989. «Juan de Quintana, Servet y los alumbrados». Argensola: Revista de Ciencias Sociales del Instituto de Estudios Altoaragoneses 102: 181-190.

${ }^{73}$ Sobre la fecha exacta de nacimiento de Servet, véase Alcalá A. (ed.), Miguel Servet. Obras completas, vol. I: XXXVII-XXXVIII.

Hispania Sacra, LXV

131, enero-junio 2013, 73-102, ISSN: 0018-215-X, doi: 10.3989/hs.2013.003 
que daría los primeros pasos escolares con su padre y con alguno de los frailes que, para atender a las monjas del monasterio sijenense, constituían una comunidad complementaria. Probablemente fuera enviado después como alumno al vecino monasterio-castillo de Montearagón. Lo que sí es seguro es que en 1525, cuando contaba catorce o quince años, Servet dejó definitivamente su tierra para no volver. El motivo que lo empujó a salir fue el hecho de convertirse en paje y secretario de Juan de Quintana, un clérigo de origen oscense como él, al que le había presentado su padre. ${ }^{74}$ Quintana era un hombre extraordinariamente capaz e influyente. Doctor por la Universidad de París y miembro prominente de las Cortes de Aragón, llegó a ser teólogo imperial, actuando como consejero de Carlos $\mathrm{V}$ en su triple faceta de predicador, confesor y capellán. Su posición privilegiada no le impidió, sin embargo, mantener a lo largo de toda su vida un espíritu erasmista - inclinado hacia la religiosidad interior-, así como un talante conciliador, abierto al diálogo con las nuevas corrientes. La huella que sin duda dejó en el joven Servet en los cinco años de formación que pasó junto a él tuvo que ser decisiva. ${ }^{75}$

Servet dispuso de dos años libres (1528-1529) para estudiar Derecho en la Universidad de Toulouse, pero sus estudios fueron interrumpidos cuando fue llamado de nuevo al servicio de Quintana. Debía acompañarlo a Bolonia para la coronación del emperador Carlos V, y luego a Alemania, con la esperanza de lograr un arreglo del problema luterano. La experiencia de presenciar la coronación imperial, esto es, de contemplar al Emperador pero, sobre todo, al Papa, en todo su boato y esplendor, marcó un antes y un después en la sensibilidad de Servet, para quien todo aquel lujo y magnificencia constituían las antípodas del mensaje cristiano original, centrado en el cultivo del espíritu. ${ }^{76}$

Lo que resulta más significativo es que, justamente antes de este acontecimiento, Juan de Quintana (que ya asesorara en materia de luteranos en Bruselas

\footnotetext{
${ }^{74}$ Según Vincencio Blasco de Lanuza, Quintana era natural de Sariñena (Huesca) Véase su libro de 1622, Historias eclesiásticas y seculares de Aragón: 465. Zaragoza: Juan de Bonilla.

${ }^{75}$ Véanse Bainton, R. H. 1972. Hunted heretic. The life and death of Michael Servetus Boston: Beacon Press, 1972 (trad. esp. 1973. Servet, el hereje perseguido Madrid: Taurus); y A. Alcalá (ed.), Miguel Servet. Obras completas, vol. I: I-CX.

${ }^{76}$ La profunda huella que dejó en Servet su asistencia a la coronación del emperador se revela en la ferocidad de las palabras que escribiría a propósito del Papa, más de veinte años después de dicho acontecimiento: «Con mis propios ojos vi yo mismo cómo los principes le llevaban con pompa sobre sus hombros, mientras fulminaba cruces con la mano, y cómo le adoraba todo el pueblo de rodillas a lo largo de las calles. Llegaban al extremo de que los que habían podido besar sus pies o sus sandalias se consideraban más afortunados que los demás, y proclamaban que habían obtenido numerosas indulgencias, gracias a las cuales les serían reducidos largos años de sufrimientos infernales: ¡Oh, Bestia, la más vil de las bestias, la más desvergonzada de las rameras!», Christianismi Restitutio, IV, II, II, en A. Alcalá (ed.), Miguel Servet. Obras completas, vol. VI: 1093.
} 
en 1521-1522), había dedicado cinco años al servicio de la Inquisición española, como calificador en el asunto de los alumbrados (1525-1529), como visitador de los moriscos de Granada (1526) y como examinador de las doctrinas de Erasmo en la congregación de Valladolid (1527). De hecho, Quintana fue el autor del conocido como primer edicto de la Inquisición contra los alumbrados (1525). No obstante, más que en «contra» de los alumbrados, la actuación de Quintana iba a caracterizarse por un claro intento de conciliación. Ello se demuestra en la carta que escribió al Inquisidor General para acompañar a los sumarios o resúmenes de los procesos contra Pedro de Alcaraz, Isabel de la Cruz y Gaspar de Bedoya, que él mismo se había ocupado de redactar en 1529.

En esta carta, que constituye uno de los más claros ejemplos de tolerancia por parte de la Inquisición española, Quintana, a modo de un auténtico «abogado de los alumbrados», pedía «que no se proceda contra ellos según el rigor de la ley, y esto por muchas razones». ${ }^{77}$ La primera era que los mismos acusados se habían mostrado humildes y habían pedido perdón por sus errores. La segunda, que no habían practicado rituales judaicos o mahometanos, ni tampoco habían incurrido en herejía contra ningún artículo de la fe, sino que más bien se habían centrado en rechazar las ceremonias de la Iglesia. Por si fuera poco, Quintana añadía como descargo para sus defendidos su absoluta falta de responsabilidad. Y, para ello, nada mejor que echar la culpa al diablo quien, una vez más, habría hecho de las suyas, engañando a unos inocentes que únicamente querían perfeccionarse y amar a Dios. ${ }^{78}$ Como en tantas otras ocasiones a lo largo de la historia de la Inquisición española, el diablo iba a representar la mejor de las coartadas para justificar y pasar por alto cualquier conducta sospechosa. Figura proteica donde las haya, siempre podía reivindicarse como el autor de todo tipo de fechorías o, al menos, como la mala intención atribuida a quienes, en realidad, habían sido desviados por él. ${ }^{79}$

\footnotetext{
${ }^{77}$ Carta Autógrafa del Dr. Juan de Quintana al Inquisidor General, Don Alonso Manrique. Toledo, 14 de abril de 1529, fols. 408r-408v. Véanse el original latín y su traducción al español, en Márquez, A. 1980: 239-242.

${ }^{78}$ «Sutilmente y con gravísima tentación, fueron engañados por el demonio, transfigurado en ángel de luz, que les tentaba bajo especie de santidad [...] fueron tentados sobre algo que a primera vista parecía devoto y que a su parecer conducía a la perfección de su estado, y al puro, perfecto y absoluto amor de Dios dentro de los límites del Evangelio». Véase Márquez, A. 1980: 241.

${ }^{79}$ De la utilización del demonio como figura exculpatoria por parte de la Inquisición española podrían citarse muchos casos. Especialmente elocuentes son los que se describen en Nalle, S. 2001. Mad for God. Bartolomé Sánchez, the Secret Messiah of Cardenete Charlottesville y Londres: University Press of Virginia (trad. esp. 2009. Loco por Dios. Bartolomé Sánchez, el Mesías secreto de Cardenete Cuenca: Fundación de Cultura Ciudad de Cuenca) y Tausiet, M. 2011. «El guardián del infierno: demonología y misticismo en la España barroca», en R. Izquierdo Benito y F. Martínez Gil (eds.), Religión y heterodoxias en el mundo hispánico (ss. XIV-XVIII): 83-107. Madrid: Sílex.
} 
El cuarto argumento exculpatorio presentado por Quintana representaba un paso más allá en sus razonamientos, ya que se refería a la dificultad y sutileza de la materia que estaba tratándose. Bien pudiera ser que, dada la dificultad para entender el mensaje que pretendían transmitir los acusados, quienes habían testificado contra ellos los hubieran malinterpretado de principio a fin. El quinto argumento complementaba el anterior, al añadir que las proposiciones alumbradas estaban provistas de múltiples sentidos, por lo que una interpretación literal de las mismas fácilmente podía conducir a conclusiones falsas. Quintana acababa su carta con una frase que no podía ser más clara y contundente, y que reflejaba su carácter eminentemente conciliador: «En conclusión, mi humilde parecer, procediendo según lo alegado y probado, inclinándome más a misericordia que a rigor de justicia, es que estos dos, a saber, Alcaraz e Isabel de la Cruz, sean recibidos a reconciliación, con hábito y confiscación de bienes». En cuanto a Gaspar de Bedoya, el tercer acusado, a quien juzgaba más inofensivo aún que los anteriores, bastaba con que fuera recluido «en algún monasterio por espacio de tres meses». ${ }^{80}$

Resulta imposible probar hasta qué punto se vio implicado Servet en el asunto de los alumbrados durante los años que pasó al servicio de Quintana. Como advierte Antonio Márquez, lo que está claro es que los sumarios de los procesos contra Alcaraz, Isabel de la Cruz y Bedoya, aunque redactados por Quintana, no fueron escritos de su puño y letra. No hay que olvidar que el secretario de Quintana era Servet, hijo de notario y conocedor del lenguaje jurídico tras sus estudios de Derecho en Toulouse. Además, aunque la Inquisición tenía sus propios escribanos, los mencionados sumarios se confeccionaron fuera del tribunal inquisitorial de distrito, en este caso el de Toledo. Estas y otras circunstancias apuntan a que el amanuense de los principales documentos inquisitoriales referidos a los primeros alumbrados fuera con mucha probabilidad el propio Servet. Según Márquez, dicha hipótesis establece una estrecha relación entre quien ha sido considerado el «hereje total» $\mathrm{y}$ «la gran herejía del siglo [...] cuyo origen se da en España precisamente en esas fechas». ${ }^{81}$

La calificación de herejes, aplicada tanto a los alumbrados como, años más tarde, al propio Servet, terminaría prevaleciendo, pese a la actitud conciliadora y abierta de ciertos teólogos como Juan de Quintana. La ambigüedad del concepto de herejía, no obstante, se pone de manifiesto cuando nos adentramos en la filosofía del gran heterodoxo español por antonomasia. Más que por definirse contra doctrinas o dogmas establecidos, el pensamiento de Servet se caracteriza por su inagotable creatividad, por su interpretación personal de la tradición

\footnotetext{
${ }^{80}$ Véase Márquez, A. 1980: 241.

${ }^{81}$ Véase Márquez, A. 1989: 188-190.
} 
bíblica y por su interiorización y vivencia de la fe como una experiencia auténticamente transformadora. Dotado de una voracidad intelectual sin límites y de un temperamento apasionado e independiente, la libre trayectoria de Servet iba a producir un escándalo tras otro, no sólo en el ámbito católico, sino aún más en el protestante. Y ello quizá debido menos al peligro objetivo que entrañaban sus ideas que a la fiereza con que las defendió. Aunque, precisamente por su carácter emotivo y vehemente, la terminología servetiana pueda resultar en ocasiones un tanto confusa, una lectura atenta de los principales hilos temáticos que ordenan su obra nos permite adentrarnos en los problemas que flotaban en el ambiente religioso que respiró y, en buena medida, compartió con los llamados alumbrados. ${ }^{82}$

\section{Claroscuros}

En el afán de Servet por liberar al hombre del mundo material y espiritualizar su existencia al máximo, las alegorías en torno a la luz y la sombra desempeñan un papel central dentro de su obra. Si hay una forma en la que el espíritu invisible se manifiesta de manera comprensible, ésta es para él la luz, ${ }^{83}$ «luz creada» que cobra su significado «por analogía con la increada». ${ }^{84}$ Dicha identificación luz /espíritu le lleva a escribir con exaltación párrafos como el que sigue:

«La luz es lo más hermoso de este mundo, y del otro. Todo ser consiste en la idea misma de luz en la que resplandece. Luz y sólo luz informa y transforma todos los seres, celestes y terrestres, espirituales y corporales. De luz procede toda esta hermosura y ornato del mundo [...]. Nada puede enviar por sí mismo al ojo al espejo una forma de luz o su imagen natural si no contiene luz en sí mismo [...]. Luz es la forma visible de todas las cosas. Luz es todo lo que aparece. Luz es también lo que, de diferentes maneras, transforma la materia terrena y líquida en piedras resplandecientes, en luminosas margaritas y en todas las demás cosas que formalmente vemos por medio de la luz. Y luz es lo que

${ }^{82}$ En este sentido, resulta significativo que Servet haya sido denominado como «this quixotically theological knight-errant», así como «this proud and spiritually tormented heretic». Para George. H. Williams, Servet se caracteriza por absorber empáticamente las más profundas tensiones y fisuras de la Cristiandad de su época, precisamente por aunar el impacto del humanismo renacentista, con la Reforma y los nuevos avances de la ciencia del momento. Véase Williams, G. H. 1982: 58.

${ }^{83}$ «Si es que comprendes las analogías de las cosas [...], así como en las acciones naturales todo agente se asimila [...], así en los actos divinos nos asimila a sí mismo Dios [...] y nos conforma y une consigo por la forma externa de la luz visible, y por el espíritu interno invisible». Servet, M. 20032007. Epistolae Triginta ad Ioannem Calvinum (Treinta cartas a Calvino), V, en A. Alcalá (ed.), Obras completas, vol. IV: 24.

${ }^{84}$ «El verbo en que consisten todas las cosas es luz; en virtud de esa luz, todas las cosas consisten en el Cristo; y todas ellas son soportadas y sustentadas por su poder. Todo esto puede aplicarse también a la luz creada por analogía con la increada». Véase Servet, M. 2003-2007. Christianismi Restitutio (La restitución del cristianismo), I, IV, en A. Alcalá (ed.), Obras completas, vol. V.1: 255-256.

Hispania Sacra, LXV

131, enero-junio 2013, 73-102, ISSN: 0018-215-X, doi: 10.3989/hs.2013.003 
en la regeneración transforma e informa nuestro espíritu, como luz será también lo que transformará nuestros cuerpos en la resurreción final». ${ }^{85}$

Para Servet, el entendimiento es una forma de luz ( «la luz de tu mente, esa luz con la que me ves interiormente»), que «pone en contacto lo corporal con lo espiritual, contiene en sí todas las cosas y las pone de manifiesto con toda claridad a la contemplación de los ojos» ${ }^{86} \mathrm{La}$ insistencia de Servet en la claridad, inseparable para él de la auténtica vida espiritual, le impulsa incluso a formular toda una escatología, preñada de imágenes poderosas, en torno a la oposición luz/sombra. De acuerdo con su visión de las realidades últimas, y como ya lo había expresado Platón en el mito de la caverna ${ }^{87}$ para Servet el mundo sensible es sólo una sombra:

«Este mundo [...] es sólo 'vanidad de vanidades'. Algo que no es. Pura imagen y sombra de otro que realmente es, a saber: el mundo inteligible». ${ }^{88}$

Dicho razonamiento le lleva a concluir que «la verdad» se encuentra en otra parte:

«Ahora bien, en lo que no es, no hay verdad. Luego en este mundo no hay verdad alguna, y quien tiene verdad 'no es de este mundo'. Si parece haber algo de verdad en las cosas, se trata más bien de simulacros y sombras pasajeras de verdad». ${ }^{89}$

Teniendo en cuenta que la única luz (espíritu, entendimiento) procede de Dios, nada de lo demás importa, bañado como de hecho está en las sombras del no ser:

${ }^{85}$ Servet, M. 2003-2007. Christianismi Restitutio (La restitución del cristianismo), I, IV, en A. Alcalá (ed.), Obras completas, vol. V.1: 256-257.

${ }^{86}$ Ibídem: 250.

${ }^{87}$ La influencia de Platón y de su teoría de las ideas, arquetipos o formas sustanciales (ejemplares perfectos) de las cosas que existen eternamente en el pensamiento divino, se manifiesta con claridad en la teología de la luz de Servet: «Desde la eternidad había en Dios imágenes o representaciones de todas las cosas resplandeciendo en la sabiduría, en la palabra de Dios, como en un mundo arquetipo. Dios veía en sí mismo, en su propia luz, todas las cosas, ya que tenía en sí mismo las ideas de todas ellas como resplandeciendo en un espejo». Véase Servet, M. 2003-2007. Christianismi Restitutio (La restitución del cristianismo), I, IV, en A. Alcalá (ed.), Obras completas, vol. V. 1: 233. Véase también Hirsch, E. F. 1980. "Michael Servetus and the Neoplatonic Tradition". Bibliothèque d'Humanisme et de Renaissance 42: 561-576.

${ }^{88}$ Servet, M. 2003-2007. Christianismi Restitutio (La restitución del cristianismo), I, IV, en A. Alcalá (ed.), Obras completas, vol. V.1: 252.

${ }^{89}$ Ibídem: 252. 


\begin{abstract}
«El mundo entero, muerte e infierno pasan como sombra. Sombra fue aquella primera muerte que nos resolvía en sombra. Sombra fue de otra muerte, de la eterna, que ha de acaecer en el Juicio Final [...]. También las enfermedades que aquí nos aquejan no son más que sombra de las futuras aflicciones. El Cristo arrancará allí [a los bienaventurados] toda enfermedad, una vez desplazado el demonio, que era nuestra enfermedad y nuestra muerte»..$^{90}$
\end{abstract}

Para Servet, si por algo se caracterizan el demonio y el infierno es precisamente por la ausencia de esta luz divina: ${ }^{91}$

«Después del Juicio Final se apagará la luz del sol, y pasará como sombra [...]. Cuando las almas de los impíos sean arrojadas junto con sus cuerpos a horrendas tinieblas por justo juicio de Dios, serán despojadas de la luz de Dios». ${ }^{2}$

En última instancia, todo lo que no es Dios (logos o sabiduría, «mente admirable en que resplandecen visiblemente todas las cosas [...], para nosotros luz del entendimiento ${ }^{93}$ ) remite a la más absoluta oscuridad, a las tinieblas y, en el fondo, a la nada:

«Digo en conclusión que cuerpo, alma, muerte, infierno, todos los juicios anteriores, todos los conocimientos, todas las ciencias, todo lo visto, oído, olido, gustado y tocado, todos los ministerios de ángeles y demonios, así como cielo, Tierra, Sol, Luna y todo lo demás, fueron transitorios, pasaron como sombra, y no hubo en ellos más verdad que ser sombra de esta tan grande y perdurable verdad. Sólo en el Cristo hay verdad y eternidad». ${ }^{94}$

La figura de Cristo es invocada por Servet como sinónimo de luz, pero también de liberación. En su particular cosmogonía, la historia de la humanidad se divide en tres etapas que representan una iluminación o comunicación progresiva del Dios-espíritu, una paulatina deificación del universo en su totalidad, y del hombre en particular. La primera etapa se corresponde con el Antiguo Testamento; la segunda, con el Nuevo Testamento (identificado con Cristo); y la tercera, con la eclosión espiritual de quienes son capaces de interiorizar el auténtico mensaje cristiano. Para Servet, estas etapas no son sólo aplicables al

\footnotetext{
${ }^{90}$ Servet, M. 2003-2007. Christianismi Restitutio (La restitución del cristianismo), II, I, en A. Alcalá (ed.), Obras completas, vol. V.1: 416.

${ }^{91}$ «El diablo [...] huye de la luz». Véase Servet, M. 2003-2007. Christianismi Restitutio (La restitución del cristianismo), IV, I, en A. Alcalá (ed.), Obras completas, vol. VI: 939.

${ }^{92}$ Servet, M. 2003-2007. Christianismi Restitutio (La restitución del cristianismo), II, I, en A. Alcalá (ed.), Obras completas, vol. V.1: 370.

${ }^{93}$ Ibídem: 235.

${ }^{94}$ Ibídem: 419.
}

Hispania Sacra, LXV

131, enero-junio 2013, 73-102, ISSN: 0018-215-X, doi: 10.3989/hs.2013.003 
curso de la historia cronológica, sino a todos los acontecimientos y misterios que, en el lenguaje alegórico de la luz, presentan una fase oscura, otra corpórea y otra espiritual o luminosa (in umbra, in corpore, in spiritu):

«Hay tres etapas distintas en los misterios del Cristo: antes de la encarnación, en sombra; por la encarnación, en la debilidad del cuerpo; después de la resurrección, en gloria y poder. En la analogía de este triple modo de dispensación radican todos los misterios del mundo»..$^{95}$

La primera etapa, que Servet identifica con la Ley, presupondría el triunfo de la norma aplicada por un Dios concebido como Padre severo que premia y castiga a los hombres de acuerdo con los pecados o transgresiones a dicha Ley. Por contraste, la segunda etapa implicaría, gracias a la Encarnación, una nueva y revolucionaria visión de Dios, ya no justiciero sino compasivo. Más o menos oculto hasta entonces, el antiguo Deus absconditus habría descubierto en el Hijo su verdadero rostro, esto es, que en realidad no se encontraba sometido al esquema de la Ley, pues, una vez encarnado en la persona de Cristo, si algo había dejado claro con su vida y con su muerte es que, muy por encima de la justicia, estaba para él el amor. De este modo, la ética del Dios «nuevo», revelado en el Nuevo Testamento, no tendría nada que ver con la idea de justicia retributiva, sino con una justicia inefable, al margen de todo precepto. Si la Ley exigía un castigo por cada falta, con la muerte y resurrección de Cristo, dicho esquema habría sido destruido: Dios no lleva cuentas de los delitos. Para Servet, ello suponía la desaparición de los obstáculos que hasta entonces habían impedido una auténtica relación del hombre con lo divino y, asimismo, la eliminación del fundamento último de toda forma de dominación. De ahí que la redención se traduzca en una aproximación de la humanidad a Dios, así como en una definitva reconciliación de los seres humanos entre sí.

En la concepción servetiana, las deficiencias del Antiguo Testamento se manifestaban en forma de sombras que actuaban como «prefiguración de algo futuro [...] pues una sombra no es sino luz amortiguada»: «Existían todas esas sombras, y existía también el verbo, y con ello se quiere dar a entender la imperfección de aquel tiempo». ${ }^{96}$ Del mismo modo, las sombras de nuestra ignorancia mundana estarían prefigurando la lucidez de la iluminación espiritual:

${ }^{95}$ Servet, M. 2003-2007. Christianismi Restitutio (La restitución del cristianismo), IV, II, II, en A. Alcalá (ed.), Obras completas, vol. VI: 1085-1086.

${ }^{96}$ Servet, M. 2003-2007. Christianismi Restitutio (La restitución del cristianismo), II, I, en A. Alcalá (ed.), Obras completas, vol. V.1: 346. 
«Puede decirse que la sombra de entonces era análoga a la que hay ahora en nosotros respecto a la gloria del siglo futuro, pues 'ahora vemos como en enigma, pero entonces veremos cara a cara'». ${ }^{97}$

Las constantes imágenes en torno a la luz y a la sombra como símbolos de la progresiva manifestación de lo divino encontrarían su máxima expresión en la famosa representación de la encarnación de María, «cubierta» por la «sombra» del Altísimo. ${ }^{98}$ En palabras de Servet:

«En la Ley había luz amortiguada, nubes tenebrosas y oscuras puestas por Dios para sí mismo 'como su escondite' [...]. Sombra había entonces en ceremonias y demás misterios. El Cristo estaba entonces 'al abrigo del Altisimo', 'a la sombra del Omnipotente' [...], oculto a sombra de la palabra y a escondrijo de nube. Y esta sombra del verbo perduró aún hasta que, cubriendo con ella a María, dejó de ser sombra».99

Según la doctrina tradicional de la salvación, lo más importante de Cristo había sido su muerte-sacrificio (que el hombre-Dios muriera para aplacar a la divinidad), lo cual no planteaba niguna ruptura entre los sacrificios del Antiguo y el Nuevo Testamento. Por el contrario, para los reformadores radicales (entre ellos, especialmente, Servet), lo importante de Cristo no era tanto su muerte como su vida entera, que entrañaba un enfrentamiento con el esquema de la Ley. La pasión y muerte de Cristo en la cruz suponían una consecuencia de ese enfrentamiento: no era Dios quien había decidido sacrificar a su Hijo, sino los ricos y poderosos de este mundo. ${ }^{100}$

La figura de Cristo como libertador (del temor a la Ley, del concepto de pecado y castigo, de la obligación de realizar «buenas obras» exteriores, etc.) enlazaba por completo el espíritu de Servet con el de los alumbrados y su apología de la impecabilidad. En palabras de Servet: «La Ley nos mantenía esclavizados bajo su yugo y Cristo nos hizo libres»; «La Ley nos acusa y Cristo nos

${ }^{97}$ Ibídem: 347.

${ }^{98} \mathrm{El}$ ángel Gabriel fue enviado por Dios [...] a una virgen que estaba comprometida para casarse con un varón de nombre José, de la casa de David; y el nombre de la virgen era María. [...] El ángel le dijo [...]: «Alégrate, llena de gracia [...] Vas a concebir en tu seno, y vas a dar a luz un hijo, a quien pondrás por nombre Jesús. Él será grande y será llamado Hijo del Altísimo; y Dios le dará el trono de David, su padre, y reinará sobre la casa de Jacob por los siglos, y su reino no tendrá fin». Pero María respondió al ángel: «¿Cómo será esto, puesto que no conozco varón?». El ángel le dijo: «El Espíritu Santo vendrá sobre ti, y el poder del Altísimo te cubrirá con su sombra (Lucas, 1: 26-35).

${ }^{99}$ Servet, M. 2003-2007. Christianismi Restitutio (La restitución del cristianismo), II, I, en Ángel Alcalá (ed.), Obras completas, vol. V.1: 348.

${ }^{100}$ Sobre la doctrina tradicional de la salvación o «doctrina de la expiación», formulada en el siglo XI por Anselmo de Canterbury, véanse George H. Williams, G. H., 1962: XXXI, y González, A. 1999. Teología de la praxis evangélica. Ensayo de una teología fundamental Bilbao: Sal Terrae: 323.

Hispania Sacra, LXV

131, enero-junio 2013, 73-102, ISSN: 0018-215-X, doi: 10.3989/hs.2013.003 
es propicio»; «Por la Ley el pecado aumenta, debido a la transgresión, mientras que Cristo borró el pecado y eliminó la ocasión de transgredir». ${ }^{101}$ Una de las obsesiones más características de Servet en su constante defensa de la libertad interior consistió precisamente en advertir acerca del peligro espiritual de las normas y prohibiciones, en tanto que inducen a la desobediencia. Para Servet, las leyes humanas sólo servirían para pecar más, ya que el delito es aumentado por la ley al transgredirla:

«Es una cosa absolutamente funesta aceptar los decretos del Papa y las leyes monásticas como si nos encadenaran necesariamente a la salvación, y atarse a juramentos para guardarlos [...]. Las leyes nos convierten en reos de prevaricación, ya que el delito es aumentado por la Ley al transgredirla [...]. Sostenemos leyes humanas que ni salvan ni justifican, sino que sirven para pecar todavía más». ${ }^{102}$

«Todos nos sentimos naturalmente inclinados a lo prohibido. De modo que cuantas más cosas se prohiban a los monjes y cuantas más reglas se les den, más pecadores los harán, como a Adán y a los judíos». ${ }^{103}$

Sólo así se entiende su exhortación a la desobediencia dirigida a los frailes, en pos del verdadero espíritu comunicado por el Cristo liberador:

«En cuanto a los votos de los frailes [...] se trata de sacrilegios [...], de verdaderas bufonadas [...]. A causa de esos juramentos impera la impiedad papística [...]. Jamás una ley condujo a la perfección; incluso la misma privación de libertad es ya una imperfección [...]. A los antiguos les fue ordenado: haced votos y cumplid vuestros juramentos. Pero, proclama el Cristo, yo os digo: ¡Frailes, no hagáis votos, no hagáis juramentos, no os impongáis más yugos!» ${ }^{104}$

Si, para el alumbrado Pedro Ruiz de Alcaraz, «el dexado a Dios es impecable, de tal manera que no puede pecar ni mortal ni venialmente», ${ }^{105}$ para Servet, «Cristo [...] nos ha liberado de todos los pecados, reconciliándonos con Dios por la gracia», ${ }^{106}$ de modo que «no precisamos de ninguna obra de la Ley para

${ }^{101}$ Servet, M. 2003-2007. De Iusticia Regni Christi, ad Iusticiam legis collata, et de charitate (Sobre la justicia del reino de Cristo comparada con la justicia de la ley, y sobre la caridad), en A. Alcalá (ed.), Obras completas, vol. II.1: 471.

${ }^{102}$ Ibídem: 463.

${ }^{103}$ Servet, M. 2003-2007. Christianismi Restitutio (La restitución del cristianismo), IV, I, en A. Alcalá (ed.), Obras completas, vol. VI: 940.

${ }^{104}$ Ibídem: 1046.

${ }^{105}$ Véase Márquez, A. 1980: 247.

${ }^{106}$ Servet, M. 2003-2007. De Iusticia Regni Christi, ad Iusticiam legis collata, et de charitate (Sobre la justicia del reino de Cristo comparada con la justicia de la ley, y sobre la caridad), en A. Alcalá (ed.), Obras completas, vol. II.1: 429. 
nuestra salvación [...] pues sólo por la fe en Jesucristo se nos da la vida eterna y sólo por su gracia se anulan nuestros pecados». ${ }^{107}$

Una vez liberados del temor al pecado y de la Ley, tanto para Servet como para los alumbrados sólo quedaba la fe, entendida esencialmente como «confianza». ${ }^{108}$ Para el idealista aragonés, «la fe no puede definirse correctamente como conocimiento intelectual [...] ni es de tipo cognoscitivo», sino que «es una sustancia espiritual por la que subsistimos espiritualmente y vivimos substancialmente en Dios»; ${ }^{109}$ «la fe radica [...] en el corazón». ${ }^{110}$ Dicho énfasis en la creencia no implicaba, sin embargo, un desprecio por los actos de caridad. Frente a la clásica dicotomía fe/obras planteada por los protestantes, para Servet ambos aspectos aparecían inseparablemente unidos. ${ }^{111}$ En realidad, las buenas obras, tal y como él las entendía, sólo podían producirse como consecuencia de la fe o confianza, no de la obligación ni el miedo. ${ }^{112}$ Su característica definitoria, de hecho, sería la espontaneidad. Nada más expresivo, en ese sentido, que las palabras siguientes a propósito de la auténtica caridad:

«No sería oportuno aquí indagar más sobre las causas de las obras, sino expresarlas mejor con hechos. Pero, porque me parece que muchos filosofan erróneamente, también yo quiero exponer mi propia filosofía. Pienso que existe una causa propia y espontánea de las obras, distinta de cualquier fe y caridad. Existe un movimiento del espíritu que prorrumpe libremente en obras, aparte de toda volición o cualidad interna, pues el acto

${ }^{107}$ Ibídem: 459.

108 «Precisemos cuál es la esencia de la fe, dónde radica, cuál es su causa, cómo se forma en nosotros, hasta qué punto es espontánea, y si es acto o hábito. Afirmamos que la fe es esencialmente confianza, un acto por el cual, movidos por un cierto impulso del corazón, le creemos al Cristo, y creyendo de esa forma somos vivificados por su espíritu». Véase Servet, M. 2003-2007. Christianismi Restitutio (La restitución del cristianismo), III, I, II. En A. Alcalá (ed.), Obras completas, vol. VI: 845.

${ }^{109}$ Ibídem: 846-847.

${ }^{110}$ Ibídem: 848.

111 «Nosotros hemos sido purificados, consagrados a Cristo y justificados sin obras; pero esta justificación, sin embargo, se encauza de nuevo hacia un punto: a que nos entreguemos en todo a las buenas obras y caminemos por ellas». Véase Servet, M. 2003-2007. De Iusticia Regni Christi, ad Iusticiam legis collata, et de charitate (Sobre la justicia del reino de Cristo comparada con la justicia de la ley, y sobre la caridad), en A. Alcalá (ed.), Obras completas, vol. II.1: 468.

112 «Las obras de caridad tienen importancia con respecto a la gloria que habrá de revelarse en el mundo venidero [...]. Es más, no es cristiano quien no prepara y atesora para sí esta recompensa con todas sus fuerzas, y seríamos los más improductivos siervos si habiéndonos sido dado un talento, no ganáramos otros. Pero los ganamos sobre el fundamento de la fe [...] y no existe ahora el miedo que existía en la época de la Ley con respecto a la observancia de los mandatos». Véase Servet, M. 20032007. De Iusticia Regni Christi, ad Iusticiam legis collata, et de charitate (Sobre la justicia del reino de Cristo comparada con la justicia de la ley, y sobre la caridad), en A. Alcalá (ed.), Obras completas, vol. II.1: 472-473.

Hispania Sacra, LXV

131, enero-junio 2013, 73-102, ISSN: 0018-215-X, doi: 10.3989/hs.2013.003 
exterior está gobernado solamente por el movimiento del corazón que lanza sus espíritus a los miembros. Y este movimiento o reacción espontánea está por encima de toda volición.» ${ }^{113}$

En su ardiente defensa del espiritualismo, tanto los llamados alumbrados como Servet iban a abogar por una libertad interior sin límites, entendida como reflejo de la libertad divina. Del mismo modo que para Dios no existía ningún impedimento, para el hombre plenamente desarrollado ${ }^{114}$ la facultad de obrar libremente constituía sin duda la mejor garantía de su iluminación espiritual. En palabras del filósofo aragonés:

«Dios actúa en nosotros para que podamos obrar libremente. Él hace que podamos entender, querer y proseguir. Él nos quita los obstáculos de Satanás, siempre dispuesto a ponernos trabas. Él, una vez propuesta la verdad, nos ilumina la mente con frecuencia para que la comprendamos. Y, una vez propuesto el bien, nos mueve el corazón para que lo deseemos [...]. Del mismo modo que Adán obraba libremente [...] hace Dios que la libertad ocupe su lugar en nosotros. Aún nos queda el espíritu de la deidad innata. Aún hoy sigue inspirando Dios en nosotros al alma partícipe de deidad [...], una luz divina innata a todo hombre». ${ }^{115}$

\section{BIBLIOGRAFÍA}

Alcalá, Á. (ed.). 2003-2007. Miguel Servet. Obras completas. Zaragoza: Prensas Universitarias. Press.

Bainton, R. H. 1952. The Reformation of the Sixteenth Century. Boston: The Beacon

Bainton, R. H. 1972. Hunted heretic. The life and death of Michael Servetus Boston: Beacon Press, 1972 (trad. esp. 1973. Servet, el hereje perseguido Madrid: Taurus).

Bainton, R. H. 1977. Women of the Reformation, from Spain to Scandinavia: 18-27. Minneapolis: Augsburg.

${ }^{113}$ Ibídem: 474.

${ }^{114}$ Para Servet, madurar equivaldría a una progresiva espiritualización, siguiendo «el orden de la Naturaleza que, con la edad, nos va llevando de lo carnal a lo espiritual». Estableciendo una asociación entre la evolución personal de cada individuo y la evolución histórica primordial que, para él, coincidía con el paso del Antiguo al Nuevo Testamento, afirmaba: «Como el cambio de naturaleza, así también el cambio de edad, de Ley y de Evangelio nos convierte de niños en adultos, de carnales en espirituales». Véase Servet, M. 2003-2007. Christianismi Restitutio (La restitución del cristianismo), IV, II, I, en A. Alcalá (ed.), Obras completas, vol. VI: 1017.

${ }^{115}$ Servet, M. 2003-2007. Epistolae Triginta ad Ioannem Calvinum (Treinta cartas a Calvino), XXII, en A. Alcalá (ed.), Obras completas, vol. IV: 96. 
Bataillon, M. 1937. Erasme et l'Espagne. Recherches sur l'histoire spirituelle du хvie siècle Paris: Droz (trad. esp. 1966. Erasmo y España. Estudios sobre la historia espiritual del siglo XVI. Madrid: Fondo de Cultura Económica).

Blasco de Lanuza, V. 1622. Historias eclesiásticas y seculares de Aragón. Zaragoza: Juan de Bonilla.

Caciola, N. 2003. Discerning Spirits: Divine and Demonic Possession in the Middle Ages Ithaca: Cornell University Press.

Covarrubias, S. 1993. Tesoro de la lengua castellana o española. Barcelona: Alta Fulla.

Dickens, A. G. 1966. Reformation and Society in Sixteenth Century Europe. Londres: Thames \& Hudson.

Eckhart, Maestro. 1983. Pláticas instructivas (o Reuniones vespertinas de conversación), II, en I. M. de Brugger (ed.), Tratados y sermones. Barcelona: Edhasa.

Fénelon, F. S. de la M. 1851. Euvres complètes. París: Gaume.

Firpo, M. 1990. Tra alumbrados e 'spirituali': studi su Juan de Valdés e il valdesianesimo nella crisi religiosa del '500 italiano Florencia: Olschki (trad. esp. 2000. Entre alumbrados y «espirituales». Estudios sobre Juan de Valdés y el valdesianismo en la crisis religiosa del '500 italiano. Madrid: Fundación Universitaria Española)

Firpo, M. (trad. John Tedeschi). 1996. «The Italian Reformation and Juan de Valdés». Sixteenth Century Journal, 27, 2: 353-364.

Foley, A. E. 1986. «El alumbradismo y sus posibles orígenes», en A. D. Kossoff, G. Ribbans, J. Amor y Vázquez (eds.), Actas del VIII Congreso de la Asociación Internacional de Hispanistas. Madrid: Istmo.

Fuente de la, V. 1855. Historia eclesiástica de España. Barcelona: Riera.

Meléndez y Pelayo, M. 1947 [1ª ed. 1880-1882]. Historia de los heterodoxos españoles. Madrid: BAC.

González, A. 1999. Teología de la praxis evangélica. Ensayo de una teología fundamental Bilbao: Sal Terrae: 323.

Keitt, A. 2005. Inventing the Sacred. Imposture, Inquisition, and the Boundaries of the Supernatural in Golden Age Spain Leiden: Brill.

Lagrée, J. 1996. "Quiétude et inquiétude de la raison: Fénelon et Leibniz", en D. Leduc-Fayette (ed.), Fénelon, philosophie et spiritualité. Ginebra: Droz.

Lea, H. Ch. 1983. Historia de la Inquisición española. Madrid: Fundación Universitaria Española.

Leclerc, J. 1955. Histoire de la tolérance au siècle de la Réforme. París: F. Aubier (trad. esp. 1969. Historia de la tolerancia en el siglo de la Reforma Alcoy: Marfil).

Lerner, R. E. 1972. The Heresy of the Free Spirit in the Later Middle Ages BerkeleyLos Angeles-Londres: University of California Press. 
Libera, A. De, 1996. Eckhart, Suso, Tauler et la divinisation de l'homme. París: Bayard (trad. esp. 1999. Eckhart, Suso, Tauler y la divinización del hombre Palma de Mallorca: J. J. de Olañeta).

Llano Cifuentes, C. (ed.) 2004. Discurso sobre la dignidad del hombre. Ciudad de México: Universidad Autónoma de México.

Márquez, A. 1980. Los alumbrados. Orígenes y filosofía (1525-1559). Madrid: Taurus.

Márquez, A. 1989. «Juan de Quintana, Servet y los alumbrados». Argensola: Revista de Ciencias Sociales del Instituto de Estudios Altoaragoneses 102: 181-190.

Menéndez Pelayo, M. 1978. Historia de los alumbrados (1570-1630). Madrid: Fundación Universitaria Española.

Moreno Moreno, D. 2011. Miguel Servet, teólogo iluminado: ¿ortodoxia o herejía? Zaragoza: Institución Fernando el Católico.

Nalle, S. 2001. Mad for God. Bartolomé Sánchez, the Secret Messiah of Cardenete Charlottesville y Londres: University Press of Virginia (trad. esp. 2009. Loco por Dios. Bartolomé Sánchez, el Mesías secreto de Cardenete Cuenca: Fundación de Cultura Ciudad de Cuenca).

Ortega, M. 1978. Proceso inquisitorial contra María de Cazalla (1534). Madrid: Fundación Universitaria Española.

Ozment, S. E. 1973. Mysticism and Dissent. Religious Ideology and Social Protest in the Sixteenth Century. New Haven y Londres: Yale University Press.

Pastore, S. 2004. Un'eresia spagnola: Spiritualità conversa, alumbradismo e inquisizione (1449-1559) Florencia: Olschki (trad. esp. 2010. Una herejía española. Conversos, alumbrados e Inquisición (1449-1559) Madrid: Marcial Pons).

Pego Puigbó, A. 2004. El Renacimiento Espiritual. Introducción literaria a los tratados de oración españoles (1520-1566) Madrid: CSIC.

Santonja, P. 2000. «Las doctrinas de los alumbrados españoles y sus posibles fuentes medievales». Dicenda. Cuadernos de Filología Hispánica 18: 353-392.

Selke, A. 1968. El Santo Oficio de la Inquisición: proceso de Fr. Francisco Ortiz Madrid: Guadarrama.

Serrano y Sanz, M. 1903. «Pedro Ruiz Alcaraz, iluminado alcarreño del siglo XVI». Revista de Archivos, Bibliotecas y Museos VIII: 2.

Sluhovsky, M. 2007. Believe Not Every Spirit. Possession, Mysticism, \& Discernment in Early Modern Catholicism Chicago: University of Chicago Press.

Tausiet, M. 2010. «Mago contra Falsario: Un duelo de insultos entre Calvino y Servet. Hispania Sacra, 62, 125: 181-211.

Tausiet, M. 2011. «El guardián del infierno: demonología y misticismo en la España barroca», en R. Izquierdo Benito y F. Martínez Gil (eds.), Religión y heterodoxias en el mundo hispánico (ss. XIV-XVIII): 83-107. Madrid: Sílex. 
Varillon, F. 1957. Fénelon et le pur amour. París: Seuil.

Williams, G. H. 1962. The Radical Reformation: XII Kirksville: Sixteenth Century Journal Publishers (versión resumida traducida el español en 1983. La reforma radical, Ciudad de México: Fondo de Cultura Económica). 